\title{
MODEL PAIR CHECK UNTUK MENINGKATKAN HASIL BELAJAR MATEMATIKA MATERI PECAHAN PADA SISWA KELAS V SEKOLAH DASAR
}

\author{
Wendri Wiratsiwi ${ }^{1}$, Miftahur Rohmah ${ }^{2}$ \\ ${ }^{12}$ Universitas PGRI Ronggolawe Tuban \\ wendriwiratsiwi3489@gmail.com
}

\begin{abstract}
This study aims to improve mathematics learning outcomes in fractional material in fifth grade elementary school students. The research method used is a class action research method. The subjects in this study were fifth grade students of Temaji I Elementary School, Jenu District, Tuban with 32 students including 14 men and 18 women. Data collection techniques through observation techniques with observation of teacher activities and student activities and test techniques. The results showed an increase from pre-cycle, which was previously only 10 students (31.25\%) who reached the minimum completeness criteria increased to 14 students (43.75\%) who completed learning, in the second cycle increased to 19 students (59.4\%) and in cycle III also increased to 27 students (84.3\%) who reached the minimum completeness criteria.
\end{abstract}

Keywords: pair check model, learning outcomes, fractions

\begin{abstract}
Abstrak
Penelitian ini bertujuan untuk meningkatkan hasil belajar Matematika materi pecahan pada siswa kelas $\mathrm{V}$ sekolah dasar. Metode penelitian yang digunakan adalah metode penelitian tindakan kelas. Subjek dalam penelitian ini adalah siswa kelas V Sekolah Dasar Negeri Temaji I Kecamatan Jenu Kabupaten Tuban dengan jumlah siswa sebanyak 32 siswa meliputi laki-laki 14 dan 18 perempuan. Teknik pengumpulan data melalui teknik observasi dengan observasi aktivitas guru dan aktivitas siswa serta teknik tes. Hasil penelitian menunjukkan terjadi peningkatan dari pra siklus yaitu sebelumnya hanya 10 siswa $(31,25 \%)$ yang mencapai kriteria ketuntasan mnimal meningkat menjadi 14 siswa $(43,75 \%)$ yang tuntas belajar, pada siklus II meningkat menjadi 19 siswa $(59,4 \%)$ dan pada siklus III juga meningkat menjadi 27 siswa $(84,3 \%)$ yang mencapai kriteria ketuntasan mnimal.
\end{abstract}

Keywords: model pair check, hasil belajar, pecahan

\section{PENDAHULUAN}

Sekolah Dasar merupakan salah satu lembaga pendidikan yang menjalankan aktivitas pembelajaran yakni usaha untuk membuat peserta didik belajar. Anna Poedjiadi (dalam Trianto, 2010:), memaknai pembelajaran sebagai proses interaksi yang dilakukan oleh guru dan siswa, baik di dalam maupun di luar kelas dengan menggunakan berbagai sumber belajar sebagai bahan kajian.

Supaya siswa mengalami proses pembelajaran yang efektif, maka kita sebagai seorang pendidik harus merancang pembelajaran agar siswa terlibat secara aktif dalam proses belajar. Cara yang dapat dilakukan guru antara lain dengan 
menggunakan metode, model, dan media yang tepat dan menarik. Penggunaan alternatif tersebut diharapkan dapat memicu timbulnya partisipasi aktif pada setiap mata pelajaran. Tentunya setiap mata pelajaran maupun materi mempunyai ciri sendiri dalam penggunaan metode, model dan media yang tepat, termasuk pada mata pelajaran Matematika.

Berdasarkan hasil observasi di SDN Temaji I kelas V, ketika pembelajaran Matematika berlangsung, aktivitas guru masih mendominasi dan jarang sekali adanya umpan balik terhadap peserta didik sehingga informasi yang didapatkan hanya sebatas kemampuan dari guru tersebut dan pembelajaran pun jadi monoton, sikap sosial peserta didik masih kurang dan peserta didik kurang memperhatikan materi yang sedang diberikan, dan masih banyak hambatan karena dari guru belum menggunakan media maupun model yang baru sesuai dengan perkembangan zaman yang sesuai dengan materi yang akan diberikan supaya pembelajaran akan lebih menarik dan menyenangkan. Disisi lain kemampuan siswa juga berbeda-beda dalam menangkap pelajaran yang diberikan oleh guru Jadi, untuk itu kita juga harus kreatif dalam melakukan pembelajaran karena untuk menarik anak supaya mempunyai hasil maksimal dan setelah itu anak akan lebih suka dengan pembelajaran yang akan diberikan.
Akibatnya berdampak pada hasil belajar siswa yang didapatkan tergolong rendah dan masih di bawah Kriteria Ketuntasan Minimal (KKM) pada mata pelajaran Matematika yang ditetapkan yaitu 73. Bersadarkan data hasil belajar dengan materi pecahan menunjukkan bahwa dari 32 siswa yang mencapai KKM hanya $31,25 \%$ sedangkan sisanya $68,75 \%$ belum mencapai KKM.

Salah satu model pembelajaran yang tepat untuk meningkatkan hasil belajar Matematika materi Pecahan pada Siswa Kelas V adalah dengan menerapkan model Pair Check. Alasan memilih Pair Check sebagai model pembelajaran pada penelitian ini dikarenakan langkah-langkah pembelajaran Pair Check berpusat pada siswa, modelnya sederhana, hal ini sesuai dengan penjelasan sebelumnya bahwa jika siswa aktif dalam pembelajaran maka hasil belajarnya juga akan mencapai KKM bahkan akan melampaui nilai KKM. Menurut Herdian (dalam Shoimin, 2009:119) model pair check (pasangan mengecek) merupakan model pembelajaran dimana siswa saling berpasangan dan menyelesaikan persoalan yang diberikan.Dalam model pembelajaran kooperatif tipe pair check, guru bertindak sebagai motivator dan fasilitator aktivitas siswa. Model pembelajaran ini juga untuk melatih rasa sosial siswa, kerja sama, dan kemampuan memberi penilaian. 
Model pair check ini merupakan pembelajaran kooperatif yang menuntut kemandirian dan kemampuan siswa dalam menyelesaikan persoalan (Huda, 2013:211).

Menurut Herdian (dalam Shoimin, 2009:119) model pair check (pasangan mengecek) merupakan model pembelajaran dimana siswa saling berpasangan dan menyelesaikan persoalan yang diberikan. Dalam model pembelajaran kooperatif tipe pair check, guru bertindak sebagai motivator dan fasilitator aktivitas siswa. Model pembelajaran ini juga untuk melatih rasa sosial siswa, kerja sama, dan kemampuan memberi penilaian. Model ini bertujuan untuk meningkatkan kemampuan siswa dalam menuangkan ide, pikiran, pengalaman, dan pendapatnya dengan benar. Dengan strategi pair check memungkinkan bagi siswa untuk saling bertukar pendapat dan memberikan tugas.

Kelebihan model Pair Check Menurut Huda (2013:212) kelebihan pair check antara lain : Meningkatkan kerja sama antar siswa. Peer tutoring. Meningkatkan pemahaman atas konsep atau proses pembelajaran. Melatih siswa berkomunikasi dengan baik dengan teman sebangkunya. Sedangkan kekurangan model pair check menurut Huda (2013:212) kekurangan pair check antara lain : Waktu yang benar-benar memadai. Dan kesiapan siswa untuk menjadi pelatih dan partner yang jujur dan memahami soal.

\section{METODE}

Penelitian ini merupakan penelitian tindakan kelas (PTK) yakni penelitian yang bertujuan untuk memperbaiki suatu keadaan pembelajaran di kelas dengan melakukan tindakan-tindakan tertentu. Satu siklus terdiri 4 tahapan sebagai berikut: Perencanaan, Pelaksanaan, Pengamatan, dan Refleksi. Kegiatan tersebut merupakan langkah-langkah berurutan dalam satu siklus yang saling berhubungan dengan siklus berikutnya. Penelitian ini menggunakan rancangan peneliti milik Kemmis dan Mc Taggart (dalam Arikunto, 2013:137)

Penelitian tindakan kelas (PTK) ini dilaksanakan di SDN Temaji I yang beralamatkan di Dusun Karanganyar Gang II Desa Temaji Kecamatan Jenu Kabupaten Tuban.

Waktu penelitian adalah waktu berlangsungnya penelitian atau saat penelitian ini dilangsungkan. Penelitian ini dilaksanakan selama 3 bulan yaitu pada bulan Pebruari, April dan Mei disaat pembelajaran berlangsung pada semester genap tahun pelajaran 2017/ 2018. Subjek penelitian dalam penelitian ini adalah siswa kelas $\mathrm{V}$ SDN Temaji I Kecamatan Jenu Kabupaten 
Tuban dengan jumlah siswa sebanyak 32 siswa meliputi laki-laki 14 dan 18 perempuan.

Instrumen penelitian lembar observasi pada penelitian ini lembar observasi aktivitas guru dan lembar aktivitas siswa yang befungsi untuk mengobservasi aktivitas guru dan aktivitas siswa selama penerapan Model Pair Check. Dan lembar tes adalah salah satu instrumen penelitian untuk mengukur kemampuan siswa terhadap penguasaan materi.

Data hasil penelitian dianalisis menggunakan teknik analisis data sebagai berikut:

a. Aktivitas Guru dan Aktivitas Siswa

Menurut Aries (2012:95), rumus analisis data aktivitas guru sebagai berikut:

$$
\mathrm{S}=\frac{\mathrm{R}}{\mathrm{N}} \times 100 \%
$$

Keterangan

$\mathrm{S}=$ Nilai persen yang dicari

$\mathrm{R}=$ Jumlah skor aktivitas yang dilakukan

$\mathrm{N}$ = Skor maksimal dari aktivitas guru/siswa

b. Ketuntasan Belajar Klasikal

Ketuntasan klasikal $=\frac{\Sigma \text { siswa yang tuntas }}{\Sigma \text { siswa }} \times 100 \%$

(Aqib dkk, 2011:41)

Tabel 1. Kriteria Tingkat Keberhasilan Belajar Siswa (\%)

\begin{tabular}{|c|c|c|}
\hline No & $\begin{array}{c}\text { Persentase } \\
\text { Keaktifan }\end{array}$ & $\begin{array}{c}\text { Kriteria } \\
\text { Keaktifan }\end{array}$ \\
\hline 1. & $>\mathbf{8 0 \%}$ & Sangat Tinggi \\
\hline 2. & $\mathbf{6 0 - 7 9 \%}$ & Tinggi \\
\hline 3. & $\mathbf{4 0 - 5 9 \%}$ & Sedang \\
\hline 4. & $\mathbf{2 0 - 3 9 \%}$ & Rendah \\
\hline 5. & $<\mathbf{2 0 \%}$ & Sangat Rendah \\
\hline
\end{tabular}

\section{HASIL DAN PEMBAHASAN}

\section{Hasil Observasi Aktivitas Guru}

Hasil observasi terhadap guru SDN pada saat pelaksanaan pembelajaran model Pair Check mata pelajaran Matematika diperoleh hasil analisis data pada siklus I, siklus II dan Siklus III sebagai berikut:

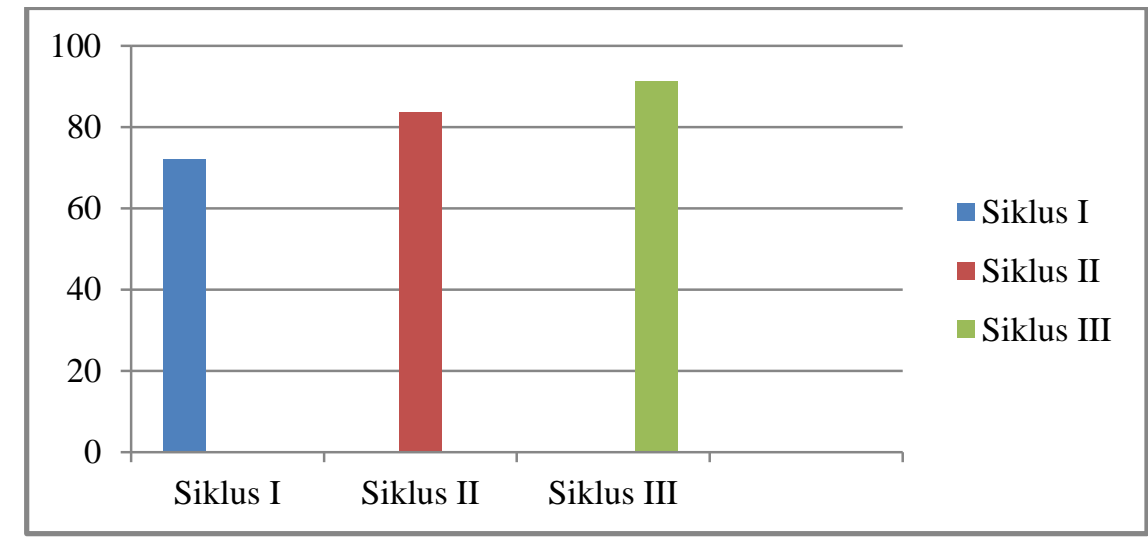

Gambar 2. Grafik Perbandingan aktivitas guru siklus I, siklus II, dan siklus III

Berdasarkan Grafik 1 diketahui perbandingan hasil observasi aktivitas guru pada siklus I mendapatkan skor 75 dengan persentase nilai $72,1 \%$ pada kriteria baik, 
sedangkan pada siklus II mendapatkan skor 87 dengan persentase nilai $83,65 \%$ dengan kriteria sangat baik, dan siklus III mendapatkan skor 95 dengan persentase nilai $91,3 \%$ pada kriteria sangat baik.

Hal ini sejalan dengan pendapat dari Huda (2013:211), sebagai berikut : guru menjelaskan konsep, guru membagikan soal kepada partner, guru membimbing dan memberikan arahan atas jawaban dari berbagai soal, dan tim yang paling banyak mendapatkan kupon diberi hadiah atau reward oleh guru. Keberhasilan pada siklus III menunjukkan bahwa pemahaman siswa dengan model pembelajaran yang diterapkan sudah dapat dipahami dan diterima dengan sangat baik oleh semua siswa dan dapat memberikan pengalaman langsung pada siswa. Dari skor yang diperoleh dari setiap siklus sudah mengalami peningkatan dengan sangat baik, mendapatkan kriteria nilai sangat baik dengan skor 4 dan untuk skor 3 mendapat kriteria nilai baik dan kriteria cukup untuk skor 2. Hal ini sudah sesuai dengan apa yang diharapkan oleh peneliti. Sehingga dapat disimpulkan dengan penerapan model Pair Check pada mata pelajaran Matematika pada materi pecahan merupakan upaya guru untuk meningkatkan keaktifan siswa dan hasil belajar siswa kelas V SDN Temaji I pada siklus I, siklus II dan siklus III, terbukti dapat dilihat dari aspek yang diamati mulai dari ketrampilan membuka pelajaran, keterampilan menjelaskan, ketrampilan memberikan pertanyaan, ketrampilan membimbing kelompok kecil dan perorangan, ketrampilan mengadakan variasi, ketrampilan memberikan penguatan, ketrampilan mengelola kelas, ketrampilan menerapkan model pair check, dan ketrampilan menutup pelajaran yang sudah meningkata dari pada siklus I dan siklus I, hal ini dapat dilihat dari nilai keaktifan guru yang mendapat kriteria "Aktif" dengan jumlah persentase $72,1 \%$ dan siklus I dan II dengan jumlah persentase $83,65 \%$ dan nilai kriteria "Sangat Aktif" pada siklus III dengan jumlah persentase 91,3\%. Siklus III merupakan tindakan perbaikan dari siklus I dan siklus II, dengan ini guru berusaha secara maksimal pada siklus III yang merupakan tahapan penyempurnaan pembelajaran dari siklus I dan siklus II.

\section{Hasil Observasi Aktivitas Siswa}

Hasil observasi terhadap aktivitas siswa pada kelas V SDN Temaji I pada saat berlangsungnya pembelajaran Model Pair Check mata pelajaran Matematika diperoleh hasil analisis data pada siklus I, siklus II, dan siklus III sebagai berikut: 


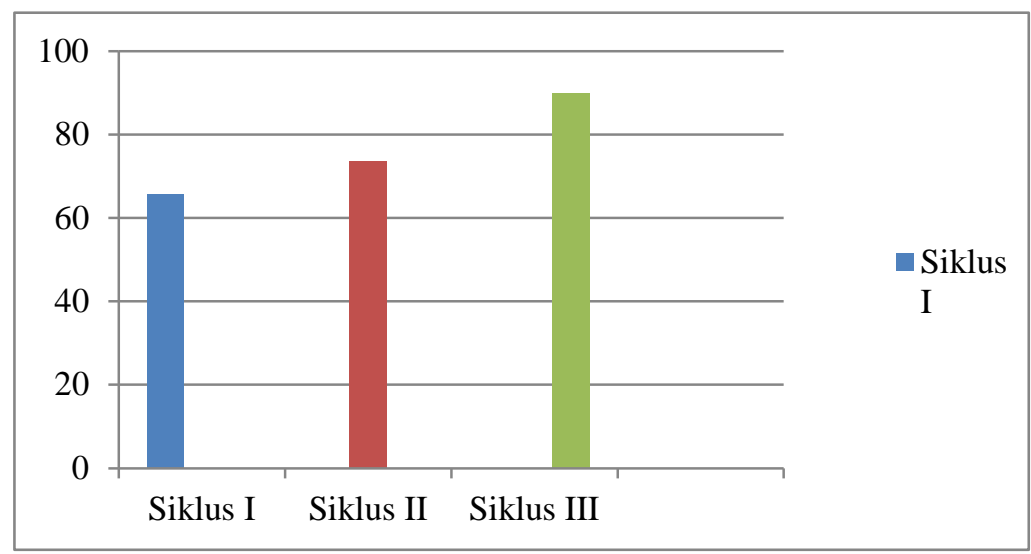

Gambar 2. Perbandingan aktivitas siswa siklus I, siklus II, dan siklus III

Berdasarkan gambar di atas bahwa aktivitas belajar siswa pada siklus I mendapat jumlah skor 421 dengan persentase $65,8 \%$, siklus II mendapat jumlah skor 475 dengan persentase $73,6 \%$ dan pada siklus III mendapat jumlah skor 576 dengan persentase $90 \%$. Hal ini sejalan dengan pendapat dari Huda (2013:212) yakni: meningkatkan kerja sama antar siswa, peer tutoring dan melatih siswa berkomunikasi dengan baik dengan teman sebangkunya, sehingga dapat disimpulkan dengan penerapan model Pair Check pada mata pelajaran Matematika pada materi pecahan dapat meningkatkan keaktifan siswa kelas V SDN Temaji I Kecamatan Jenu Kabupaten Tuban.

\section{Hasil Tes Tulis}

Hasil belajar siswa kelas V SDN Temaji I siklus I, siklus II dan siklus III diperoleh melalui tes tulis setelah pelaksanaan pembelajaran model Pair Check. Hasil analisis data hasil belajar siswa sebagai berikut:

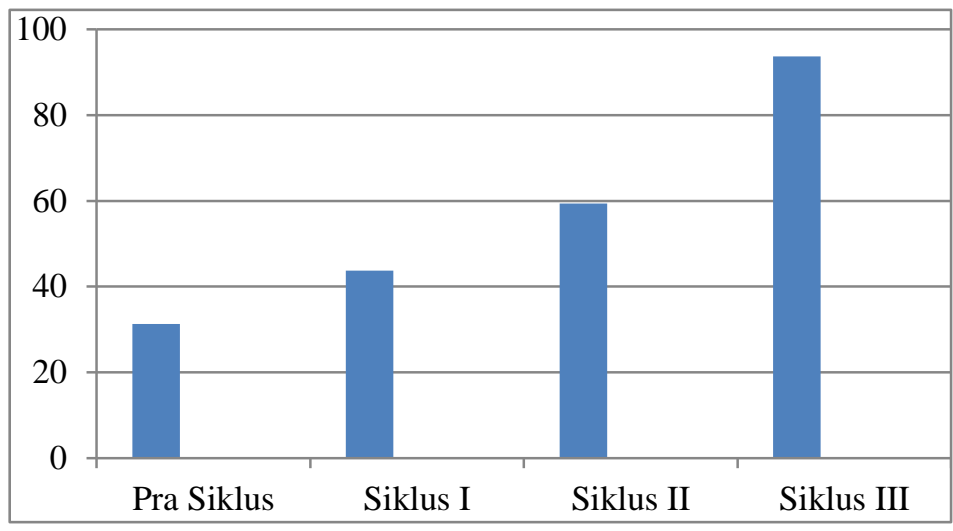


Gambar 3. Perbandingan Hasil Belajar Pra siklus, siklus I, siklus II, dan siklus III

Berdasarkan grafik 3 di atas menunjukkan bahwa ketuntasan belajar klasikal (KBK) siswa kelas V SDN Temaji I pada pra siklus telah mengalami peningkatan pada, siklus I, siklus II dan semakin meningkat pada siklus III. Dilihat dari peningkatan pada siklus III menunjukkan persentase ketuntasan belajar klasikal siswa yakni 93,7\% dengan rata-rata 84,7 dengan begitu telah melampaui nilai minimal ketuntasan belajar yakni 73 , serta dengan persentase ketuntasan belajar klasikal 93,7\% maka pada pembelajaran siklus III telah mencapai kriteria nilai "Sangat Baik", sehingga pada siklus III dinyatakan berhasil dan tidak diperlakukan tindakan selanjutnya.

\section{KESIMPULAN}

Aktivitas guru selama menerapkan model Pair Check materi pecahan pada siswa kelas V SDN Temaji I Kecamatan Jenu Kabupaten Tuban, mengalami peningkatan pada siklus II dan siklus III dibandingkan pada siklus I, persentase rata-rata keseluruhan aktivitas guru pada siklus I adalah 72,10\%, mengalamai peningkatan pada siklus II sebesar $11,55 \%$ presentase keseluruhan pada siklus II yakni sebesar $83,65 \%$, sedangkan pada siklus III mengalami peningkatan sebesar $7,65 \%$ sehingga persentase rata-rata keseluruhan aktivitas siswa pada siklus III adalah $91,30 \%$.

Aktivitas siswa selama penerapan Model Pair Check pada materi pecahan, mengalami peningkatan pada siklus II dan siklus III dibandingkan pada siklus I, persentase ratarata keseluruhan aktivitas siswa pada siklus I adalah $65,8 \%$ dan mengalami peningkatan siklus II yakni 7,8\% presentase keseluruhan pada siklus II sebesar 73,6\%, sedangkan pada siklus III mengalami peningkatan sebesar $16,4 \%$ persentase rata-rata keseluruhan aktivitas guru pada siklus III yakni $90 \%$.

Pencapaian hasil belajar siswa setelah penerapan Model Pair Check pada materi pecahan, mengalami peningkatan pada siklus II dan siklus III dibandingkan pada siklus I. Nilai rata-rata hasil belajar siswa mengalami kenaikan yakni pada siklus I dengan rata-rata 62,9 pada siklus II dengan rata-rata 75,6 dan pada siklus III mengalami peningkatan nilai rata-rata menjadi 84,7. Persentase ketuntasan belajar klasikal siswa kelas V melalui tes

\section{DAFTAR PUSTAKA}

Aqib, Z. (2011). dkk, Penelitian Tindakan Kelas Untuk Guru SD, SLB dan TK, Bandung: CV. Yrama Widya. 
Aries, E. F., Haryono, Dwi. (2012) Shoimin, A. 2(014). 68 Model Pembelajaran .Penelitian Tindakan Kelas Teori dan plikasinya.Yogyakarta:Aditya Media Publising

Trianto. (2010). Model Pembelajaran

Suharsimi. A. (2013). Prosedur Penelitian Inovatif Dalam Kurikulum 2013. Yogyakarta: Ar - Ruzz Media.

Suatu Pendekatan Praktik. Yantiani, N. M., Wiarta, I. W., \& Putra, M. Jakarta: Rineka Cipta. (2013). Pembelajaran kooperatif pair

Sugianto. D. (2010). Belajar Dan check berpengaruh terhadap hasil Pembelajaran Di Sekolah Dasar I. belajar materi bangun ruang dan bangun

Tuban: Universitas PGRI datar siswa Kelas IV Gugus IV Ronggolawe (UNIROW).

Miftahul. H. (2013). Model-Model Undiksha, 1(1).

Pengajaran dan Pembelajaran.

Yogyakarat: Pustaka Pelajar. 